\title{
EFEKTIFITAS PENDAMPINGAN PENGAWAS MINUM OBAT TERHADAP KETAATAN MINUM OBAT KLIEN TUBERKULOSIS DI PUSKESMAS WOSI MANOKWARI 2017
}

\section{EFFECTIVENESS OF DRUG DRUG SUPERVISORY SUPPLY TO DRINKING CLIENT TUBERCULOSIS DRUG IN PUSKESMAS WOSI MANOKWARI 2017}

\author{
Oktoviandi Sawasemariay, Yayuk Nuryanti
}

Poltekkes Kemenkes Sorong

\begin{abstract}
ABSTRAK
Latarbelakang : TB merupakan penyakit yang disebabkan oleh Mycobacterium tuberkulosis, umumnya menyerang paru-paru dan membutuhkan waktu pengobatan minimal enambulan. Pencapaian kesembuhan klien TB membutuhkan ketaatan minum obat. Penelitian ini bertujuan untuk mengetahui Efektivitas Pendampingan Pengawas Minum Obat (PMO) Terhadap Ketaatan Minum Obat Klien Tuberkulosis di Puskesmas Wosi Kabupaten Manokwari. Jenis penelitian quasi ekperimen dengan metode pengambilan sampel probability sampling secara simple random sampling. Sample 44 klien TB dibagi menjadi dua kelompok: intervensi dengan pendampingan PMO 22 responden dan kontrol 22 responden. Hasil penelitian sebagian besar karakteristik responden berjenis kelamin perempuan (50\%), usia 17-25 (27,2\%), 26-35 (27,2\%), pendidikan SMA-PT (50,0\%), lama menderita TB 4-6 (50,0\%), klasifikasi TB baru (86,3\%), waktu minum obat taat 20 responden $(91,0 \%)$, jenis obat taat 22 responden (100\%), dosis obat 22 responden (100\%), program 22 responden (100\%). Hasil uji chi quere didapatkan pendampaingan PMO berpengaruh terhadap ketaatan minum obat berdasarkan waktu dengan nilai $(\mathrm{p}=0,000 ;<0,05)$, sedangkan jenis obat, dosis obat dan program tidak berpengaruh dengan nilai $(\mathrm{p}=0,312 ;>0,05)$. Penelitian ini merokomendasikan perlu di bentuknya PMO di setiap keluarga yang memiliki anggota keluarga dengan TB sehingga mencegah lalai dalam waktu minum obat yang mengindikasikan gagal minum obat.
\end{abstract}

Kata kunci :Tuberkulosis, PMO, Ketaatan

Daftar Pustaka : 2007 - 2015

\author{
ABSTRACT \\ Oktoviandi Sawasemariay, Yayuk Nuryanti \\ Poltekkes Kemenkes Sorong
}

Background: TB is a disease caused by Mycobacterium tuberculosis, commonly affects the lungs and requires at least six weeks of treatment. Achieving TB clients' recovery requires medication adherence. This study aims to determine the effectiveness of Drug Supervisory Supervision (PMO) Against Drug Obedience Drugs Tuberculosis Client in Puskesmas Wosi Manokwari. Type of quasi experimental research with sampling probability sampling method by simple random sampling. Sample 44 TB clients were divided into two groups: intervention with PMO assistance 22 respondents and control 22 respondents. The results of the study were mostly female (50\%), age 17-25 (27.2\%), 26-35 (27.2\%), SMA-PT (50.0\%), long duration of TB 4 -6 (50.0\%), new tuberculosis classification (86.3\%), medication time of 20 respondents $(91.0 \%)$, medication type 22 respondents (100\%), drug dose 22 respondents $(100 \%)$, program 22 respondents (100\%). The result of chi quere test was found that PMO placement had an effect on the medication adherence based on time with value $(\mathrm{p}=0.000,<0,05)$, while drug type, drug dose and program did not affect value $(\mathrm{p}=0,312 ;>0,05)$. This study recommends that it be necessary to form PMOs in every family that has family members with $\mathrm{TB}$ so as to prevent negligence in taking medication that indicates a failure to take medication.

Keywords: Tuberculosis, PMO, Obedience

Bibliography: 2007 - 2015 


\section{A. PENDahuluan}

Tuberkulosis paru adalah penyakit yang disebabkan oleh mycobacterium tuberculosis, yakni kuman anerob yang dapat hidup terutama di paru atau berbagai tubuh yang lain seperti otak, ginjal, tulang, kelenjar getah bening. Tuberkulosis paru merupakan penyakit menular yang mempengaruhi parenkim paru. Agen infeksinya adalah Mikobacterium tuberkulosis bersifat asam dan pertumbuhannya lambat. Kuman ini juga sering berada pada daerah yang tinggi atau kaya akan oksigen sehingga bagian apical paru merupakan tempat utama perkembangan kuman tersebut (Hinkle \& Cheever, 2014; Rab, 2010; Zulkufli Amin, 2014).

Center for Disease Control and Prevention melaporkan sekitar 2 miliar orang, atau spertiga populasi dunia, terinfeksi bakteri yang menyebabkan tuberkulosis. Bakteri yang menyebabkan TB secara umum berada di seluruh dunia (WHO, 2008 dalam Ignatavicius, 2010; Black J. M, 2014).

Faktor penyebab tuberkulosis didasarkan pada kuman Mycobacterium tuberculosis berbentuk batang tahan asam dan dapat ditularkan secara cepat melalui jalur udara. Orang yang biasa terinfeksi adalah mereka yang sering kontak dengan orang-orang yang terinfeksi tuberkulosis yang belum didiagnosis. Selain itu partikel/droplet dapat melalui udara dan masuk melalui saluran pernapasan hingga menginfeksi alveolus. Jalur keluarnya droplet atau partikel tersebut melalui orang yang terinfeksi tuberkulosis pada saat berbicara, batuk, tertawa, bersin, atau bernyanyi. Risiko penularan berkurang setelah orang tersebut menerima terapi obat yang tepat selama 2 sampai 3 minggu, serta terjadi perbaikan klinis, dan pemeriksaan ulang dahak negatif (Ignatuvicius, 2010, Black J. M, 2010).

Berdasarkan

Global

Tuberkulosis Report Tahun 2015, Tuberkulosis paru membunuh 1,5 juta orang dengan tuberkulosis paru (1,1 juta HIV-negatif dan 0,4 juta HIV-positif) di tahun 2014 yang terdiri 890.000 lakilaki, 480.000 perempuan dan 140.000 anak-anak. Prevelensi tersebut bila dibandingkan dengan tahun 2013 mengalami penurunan, namun masih menjadi masalah kesehatan global di dunia. Indonesia menempati urutan ke tiga setelah India dan Cina dengan jumlah 700.000 kasus. WHO masih menunjukkan keprihatinannya kepada klien tuberkulosis dengan kasus baru yang belum teridentifikasi, klien tuberkulosis dengan HIV/AIDS, keterbatasan biaya, tingkat kemiskinan, dan letak wilayah (WHO, 2015).

Data Dinas Kesehatan Provinsi Papua Barat tentang kasus baru Tuberkulosis Paru dari tahun ke tahun terus meningkat, walaupun pelaksanaan program pemberantasan Tuberkulosis Paru terus ditingkatkan. Data BP2PL Dinas Kesehatan Provinsi Papua Barat tahun 2009 ditemukan 2462 penderita baru BTA Positif. Dari jumlah tersebut yang drop out $13,6 \%$ penderita, dan pada tahun 2010 ditemukan 2476 kasus BTA positif dengan jumlah drop out 17,8\% penderita. Ini menunjukkan adanya 
peningkatan angka drop out klien tuberkulosis dengan demikian untuk mencapai target WHO dalam penanggulangan tuberkulosis tahun 2013 dengan persentase $85 \%$, Papua Barat berada pada $77,12 \%$ yang mana belum mencapai target (Dinkes Papua Barat, 2013).

Laporan hasil rekapan kasus Tuberkulosis di Puskesmas Wosi Kabupaten Manokwari Provinsi Papua Barat terhitung bulan Januari 2016 sampai dengan Desember 2016 terdapat 281 kasus dengan insiden terbanyak yaitu laki-laki 215 kasus sedangkan wanita 66 kasus. Untuk bulan Januari sampai dengan Mei 2017 sebanyak 59 kasus. Angka insiden terbanyak laki-laki 33 kasus sedangkan wanita 26 kasus. Hasil wawancara peneliti dengan petugas P2M Puskesmas Wosi tanggal 21 Juni 2017, dari 59 kasus, 22 kasus $(37,28 \%)$ sering lalai dalam pengobatan, sedangkan gagal pengobatan sebanyak 8 kasus (13.55\%), dengan berbagai alasan. Untuk itu diperlukan sistem pencatatan dan pelaporan Puskesmas yang tertata dengan baik, dan berdasarkan masukan dari perawat pemegang program, pendelegasian dari perawat sebelumnya kepada perawat yang dipercayakan berikutnya tidak jelas bahkan tampa penyerahan dokumen.

Berdasarkan Pusat Data dan Informasi Kementerian Kesehatan Tahun (2015) tingkat keberhasilan pengobatan terendah berada di Provinsi Papua (24\%) dan tertinggi di provinsi Gorontalo (96\%). Hal ini dipengaruhi oleh beberapa faktor yaitu klien tidak patuh minum obat, klien pindah pelayanan kesehatan, resistensi obat, pengawas menelan obat tidak ada, kurangnya pemantauan pengawas menelan obat, suplai obat anti tuberkulosis terhambat sehingga klien menunda pengobatan, kualitas obat menurun karena proses penyimpanan tidak sesuai standar (Kemenkes, 2015). Hal ini diperjelas oleh hasil penelitian Tirtana (2011) tentang faktor-faktor yang mempengaruhi pengobatan, dengan jenis penelitian observasional analitik desain cross sectional pada 45 klien tuberkulosis di Rumah Sakit Dr Ario Wirawan dan Rumah Sakit Dr Moewardi sejak Januari 2006 - Desember 2009. Hasil penelitian menunjukkan bahwa ada hubungan yang bermakna antara keteraturan berobat dan lamanya pengobatan terhadap keberhasilan pengobatan dengan nilai signifikan $\mathrm{p}<$ $0,05 \%$.

Dalam upaya menurunkan angka kegagalan drop out dan mendukung terlaksananya program WHO untuk mencegah dan menemukan kasus tuberkulosis secara dini dengan capaian kesembuhan 85\%, maka diperlukan program pemerintah dalam hal ini Kementerian Kesehatan Republik Indonesia melalui Rencana Strategis Kementerian Kesehatan 2015-2019. Salah satu rencana tersebut adalah meningkatkan dan memperluas pelayanan Directly Observed Treatment Short-caourse (DOTS) atau strategi penanggulangan tuberculosis yang berkualitas agar dapat menjangkau seluruh klien tuberkulosis, meningkatkan 
penemuan kasus dan keberhasilan pengobatan, menetapkan intervensi untuk menghadapi tantangan Tuberkulosis/HIV dan Multi Drug Resistance (MDR-TB), memperkuat kemitraan dalam menyediakan akses dan standar pelayanan yang diperlukan bagi seluruh klien tuberkulosis dan berkontribusi dalam penguatan sistem kesehatan (Kemenkes, 2015).

Strategi nasional program pengendalian tuberkulosis nasional terdiri dari 7 strategi: 1) Memperluas dan meningkatkan pelayanan Diretly Observed Treatment Short-course (DOTS) yang bermutu, 2) Menghadapi tantangan tuberkulosis atau Human Immunodeficiency Virus (HIV), Multi Drug Resisaence (MDR-TB), Tuberkulosis anak dan kebutuhan masyarakat miskin serta rentan lainnya, 3) Melibatkan seluruh penyedia pelayanan pemerintah, masyarakat (sukarela), perusahaan dan swasta melalui pendekatan pelayanan tuberkulosis terpadu pemerintah dan swasta (Public Private Mix) dan menjamin kepatuhan terhadap Standar Internasional Penatalaksanaan Tuberkulosis (International Standards For TB Care), 4) Memberdayakan masyarakat dan pasien tuberkulosis, 5) Memberikan kontribusi dalam penguatan sistem kesehatan dan manajemen program pengendalian tuberkulosis, 6) Mendorong komitmen pemerintah pusat dan daerah terhadap program tuberkulosis, 7) Mendorong penelitian, pengembangan dan pemanfaatan informasi strategis (Kemenkes, 2014)
Program Directly Observed Treatment Short-course (DOTS) yang belum maksimal dijalankan, dapat mempengaruhi derajat kesehatan masyarakat pada umumnya dan khususnya masyarakat papua. Berdasarkan hasil penelitian Sineri (2013) dengan tujuan menganalisis pelaksanaan program penanggulangan tuberkulosis dengan strategi Directly Observed Treatment Short-course. Aspek yang dianalisis adalah aspek perencanaan, pengorganisasian, kerjasama, pengawasan, dan pembinaan serta dukungan unsur lingkungan. Melalui penelitian kualitatif dengan content analysis terhadap Kepala Puskesmas, Pemegang Program, Tokoh Agama, Toko Masyarakat, dan penderita tuberkulosis di Puskesmas Kabupaten Waropen Provinsi Papua. Diperoleh hasil bahwa perencanaan yang dibuat belum dilaksanakan untuk menetukan kasus baru, tidak tercapainya target penyuluhan karena ketiadaan dana, belum ada sosialisasi kader, Tokoh Masyarakat, Toko Agama, belum menyusun pokja, belum ada kerja sama antara puskesmas, lintas program maupun lintas sektoral dan keterbatasan akses geografi dan transportasi.

Pengawas Minum Obat adalah seorang yang bertugas untuk mengawasi klien agar menelan obat, berobat, memeriksakan diri, secara teratur sampai selesainya pengobatan, dan sekaligus memberikan penyuluhan pada keluarga yang memiliki risiko tuberkulosis, atau yang memiliki anggota keluarga yang menderita tuberkulosis sehingga dapat 
melakukan pencegahan sedini mungkin (Kemenkes, 2014). Berdasarkan penelitian Irawati (2014) dengan tujuan untuk mengetahui faktor-faktor yang menyebabkan kegagalan klien tuberkulosis selama menjalani pengobatan obat anti tuberkulosis di RSUD Dok II Jayapura periode Januari 2011 sampai dengan September 2012, dengan metode deskriptif menunjukkan bahwa ketiadaan pengawas minum obat berpengaruh pada ketaatan minum obat klien tuberkulosis dimana hasil penelitian menunjukkan bahwa dari 124 klien yang dijadikan sampel terdapat 35 klien gagal pengobatan dan mengalami efek samping obat serta tidak memiliki pengawas minum obat.

Berdasarkan teori dukungan sosial (Marjorie A. Schaffer). Peterson \& Bredow (2013), dukungan sosial didefinisikan sebagai " bantuan yang diberikan melalui hubungan sosial dan interaksi antara klien dan pemberi dukungan, sehingga fokus pada permasalahan yang terjadi sekaligus menjawab kebutuhan klien. Hal lain yang ditekankan pada teori ini adalah; dukungan, perhatian, kasih sayang, yang akan membuat klien merasa nyaman dan dapat menggunakan kemampuannya untuk mengatasi permasalahan yang klien hadapi. Dengan demikian dukungan yang diberikan oleh pemberi bantuan tampa harus dipaksakan, namun penuh dengan kerelaan untuk mencapai tujuan yang diinginkan bersama klien.

Menindak lanjuti permasalahan kesehatan secara global dan khusus di Povinsi Papua Barat tentunya membutuhkan pemahaman yang baik tentang kondisi, tuntutan masyarakat, budaya, serta kehiadupan sosial yang berlaku dalam wilayah tersebut sehingga dengan pendekatan yang tepat dapat dilakukan perubahan yang mengarah pada perbaikan derajat kesehatan masyarakat Papua Barat khususnya peningkatan pelayanan kesehatan bagi individu, keluarga, kelompok dan masyarakat pada umumnya terkait tuberkulosis, untuk itu peneliti bermaksud melakukan penelitian dengan judul “ Efektifitas Pendampingan Pengawas Minum Obat (PMO) terhadap Ketaatan Minum Obat Klien Tuberkulosis di Puskesmas Wosi Manokwari Provinsi Papua Barat "?

\section{B. METODE PENELITIAN}

Desain penelitian adalah panduan yang dibuat oleh peneliti untuk menjawab pertanyaan atau uji hipotesa. Desain adalah link penting yang menghubungkan kerangka dan pertanyaan penelitian dengan data yang dihasilkan. Penelitian ini merupakan penelitian kuantitatif dengan rancangan penelitian kuasi eksperimen dengan metode pengambilan sampel yaitu probability sampling secara simple random sampling yang mana dilakukan secara acak berdasarkan jumlah populasi yang tersedia dan diberi nama pada secarik kertas lalu dimasukan dalam botol dikocok lalu ditarik berdasarkan jumlah sampel yang dibutuhkan yaitu 22 dari 335 populasi yang ada, selanjutnya akan dilakukan pendampingan PMO pada kelompok intervensi dan pada kelompok kontrol 
mengikuti program pengobatan seberti biasa tampa pendampingan untuk melihat efektifitas pendampingan PMO terhadap ketaatan minum obat klien tuberkulosis yang akan dituangkan dalam skema penelitian yang teridiri dari variable independen, varibel dependen.

Desain penelitian adalah quasi experiment yaitu desain penelitian yang memberikan perlakuan pada dua atau tigakelompok. Kelompok tersebut diobservasi sebelum dan sesudah intervensi(Polit, 2010). Pengukuran variable dependen dilakukan intervensi dan kontrol, artinya pada kelompok satu diberikan intervensi dan kelompok satunya tampa intervensi.

Pasien yang ada pada kelompok intervensi akan diberikan pendampingan PMO dan diobservasi selama 1 minggu berdasarkan lembar observasi yang berisikan waktu minum obat, jenis obat, dosis obat, sesuai program. Sedangkan kelompok kontrol tetap mengikuti program pengobatan seperti biasa tampa pendampingan PMO. 


\section{HASIL PENELITIAN}

1. Analisis Univariat

a. Distribusi Frekuensi Karakteristik Responden Di Puskesmas Wosi Kabupaten Manokwari

\begin{tabular}{|c|c|c|c|c|c|c|}
\hline \multirow{2}{*}{$\begin{array}{l}\text { Varibel } \\
\text { Usia }\end{array}$} & \multicolumn{2}{|c|}{ Intervensi } & \multicolumn{2}{|c|}{ Kontrol } & \multicolumn{2}{|c|}{ Jumlah } \\
\hline & $\mathrm{n}$ & $\%$ & $\mathrm{n}$ & $\%$ & $\mathrm{n}$ & $\%$ \\
\hline $17-25$ & 6 & 27,2 & 13 & 59,0 & 19 & 43,1 \\
\hline $26-35$ & 6 & 27,2 & 3 & 14,0 & 9 & 20,3 \\
\hline $36-45$ & 3 & 13,6 & 3 & 14,0 & 6 & 14,0 \\
\hline $46-55$ & 5 & 23,0 & 1 & 4,0 & 6 & 13,6 \\
\hline$\geq 56$ & 2 & 9,0 & 2 & 9,0 & 4 & 9.0 \\
\hline Jumlah & 22 & 100 & 22 & 100 & 44 & 100 \\
\hline \multicolumn{7}{|l|}{ Jenis Kelamin } \\
\hline Laki-laki & 11 & 50 & 10 & 45,5 & 21 & 47,7 \\
\hline Perempuan & 11 & 50 & 12 & 54,5 & 23 & 52,3 \\
\hline Jumlah & 22 & 100 & 22 & 100 & 44 & 100 \\
\hline \multicolumn{7}{|l|}{ Pendidikan } \\
\hline Tdk Sekolah & 2 & 9,0 & 4 & 18,2 & 6 & 13,6 \\
\hline SD-SMP & 9 & 41,0 & 9 & 40,9 & 18 & 40,9 \\
\hline SMA-PT & 11 & 50,0 & 9 & 40,9 & 20 & 45,4 \\
\hline Jumlah & 22 & 100 & 22 & 100 & 44 & 100 \\
\hline
\end{tabular}

Lama Menderita

TB

\begin{tabular}{ccccccc} 
0-3 Bulan & 10 & 45,4 & 9 & 40,9 & 19 & 43,2 \\
4-6 Bulan & 11 & 50,0 & 10 & 45,4 & 21 & 47,7 \\
$\geq 7$ Bulan & 1 & 4,5 & 3 & 13,6 & 4 & 9,0 \\
Jumlah & 22 & 100 & 22 & 100 & 44 & 100 \\
\hline Klasifikasi TB & & & & & & \\
Baru & 19 & 86,3 & 18 & 81,8 & 37 & 84.0 \\
Berulang & 3 & 13,6 & 4 & 18,2 & 7 & 16.0 \\
\hline Jumlah & 22 & 100 & 22 & 100 & 44 & 100 \\
\hline
\end{tabular}


b. Data Khusus

Distribusi Responden Berdasarkan Ketaatan Minum Obat Penderita Tuberkulosis di Puskesmas Wosi Kabupaten Manokwari dapat dijelaskan pada tabel berikut:

1. Ketaatan Berdasarkan Waktu Pemberian

Tabel 4.2 Distribusi Ketaatan Minum Obat Responden Berdasarkan Waktu Pada Kelompok Intervensi Dan Kontrol Penderita Tuberkulosis Di Puskesmas Wosi Kabupaten Manokwari Tahun 2017

\begin{tabular}{lcccc}
\hline & \multicolumn{2}{c}{ Intervensi } & \multicolumn{2}{c}{ Kontrol } \\
Waktu Minum Obat & $\mathrm{f}$ & $\%$ & $\mathrm{f}$ & $\%$ \\
\hline Taat & 20 & 91,0 & 6 & 27,3 \\
Tidak taat & 2 & 9,0 & 16 & 72,7 \\
Jumlah & 22 & 100 & 22 & 100 \\
\hline
\end{tabular}

Berdasarkan pada tabel 4.2 Menunjukkan responden yang taat berdasarkan waktu minum obat terbanyak pada kelompok intervensi yaitu 22 responden sedangkan kelompok kontrol 6 responden.

\section{Ketaatan Berdasarkan Jenis Obat}

Tabel 4.3 Distribusi Ketaatan Minum Obat Responden Berdasarkan Jenis Obat Pada Kelompok Intervensi Dan Kontrol Penderita Tuberkulosis Di Puskesmas Wosi Kabupaten Manokwari Tahun 2017

\begin{tabular}{lcccc}
\hline & \multicolumn{2}{c}{ Intervensi } & \multicolumn{2}{c}{ Kontrol } \\
Jenis Obat & $\mathrm{f}$ & $\%$ & $\mathrm{f}$ & $\%$ \\
\hline Taat & 22 & 100 & 21 & 95,4 \\
Tidak taat & 0 & 0 & 1 & 4,6 \\
Jumlah & 22 & 100 & 22 & 100 \\
\hline
\end{tabular}

Berdasarkan Tabel 4.3 Menunjukkan responden taat berdasarkan jenis obat terbanyak pada kelompok intervensi yaitu 22 responden sedangkan kelompok kontrol 21 responden 


\section{Ketaatan Berdasarkan Dosis Obat}

Tabel 4.4 Distribusi Ketaatan Minum Obat Responden Berdasarkan Dosis Obat Pada Kelompok Intervensi dan Kontrol Penderita Tuberkulosis di Puskesmas Wosi Kabupaten Manokwari Tahun 2017

\begin{tabular}{lcccc}
\hline & \multicolumn{2}{c}{ Intervensi } & \multicolumn{2}{c}{ Kontrol } \\
Dosis Obat & $\mathrm{f}$ & $\%$ & $\mathrm{f}$ & $\%$ \\
\hline Taat & 22 & 100 & 21 & 95,4 \\
Tidak taat & 0 & 0 & 1 & 4,6 \\
Jumlah & 22 & 100 & 22 & 100 \\
\hline
\end{tabular}

Berdasarkan Tabel 4.4 Menunjukkan responden taat berdasarkan Dosis Obat terbanyak pada kelompok intervensi yaitu 22 responden sedangkan kelompok kontrol 21 responden.

\section{Ketaatan Berdasarkan Program}

Tabel 4.5 Distribusi Ketaatan Minum Obat Responden Berdasarkan Program Pada Kelompok Intervensi Dan Kontrol Penderita Tuberkulosis Di Puskesmas Wosi Kapupaten Manokwari Tahun 2017

\begin{tabular}{lcccc}
\hline & \multicolumn{2}{c}{ Intervensi } & \multicolumn{2}{c}{ Kontrol } \\
Program & $\mathrm{f}$ & $\%$ & $\mathrm{f}$ & $\%$ \\
\hline Taat & 22 & 100 & 21 & 95,4 \\
Tidak taat & 0 & 0 & 1 & 4,6 \\
Jumlah & 22 & 100 & 22 & 100 \\
\hline
\end{tabular}

Berdasarkan Tabel 4.5 Menunjukkan responden taat berdasarkan Program terbanyak pada kelompok intervensi yaitu 22 responden sedangkan kelompok kontrol 21 responden.

\section{Analisis Pengaruh Pendampingan PMO terhadap Ketaatan Minum Obat} Hasil uji statistik dengan Chi Squareuntuk melihat pengaruh pendampingan PMO terhadap ketaatan minum obat dijelaskan pada tabel 4.6 berikut. Dari hasil uji statistik didapatkan responden dengan ketaatan berdasarkan waktu dengan nilai significancy 0,000 atau $\mathrm{p}<0,05$ artinya terdapat hubungan antara dukungan PMO dengan ketaatan berdasarkan waktu pemberian obat. Sedangkan ketataan berdasarkan jenis obat, dosis obat dan sesuai program dengan nilai significancy masing-masing 0,312 atau $\mathrm{p}>0,05$ artinya tidak ada hubungan antara dukungan PMO dengan ketaatan minum obat berdasarkan jenis obat, dosis obat dan program. 
Tabel 4.6 Pengaruh Pendampingan PMO Terhadap Ketaatan Minum Obat Klien Tuberkulosi Pada Kelompok Intervensi dan Kelompok Kontrol Di Puskesmas Wosi Kapupaten Manokwari

\begin{tabular}{lccccc}
\hline Variabel & \multicolumn{2}{c}{ Intervensi } & \multicolumn{2}{c}{ Kontrol } & $\mathrm{p}$ \\
\cline { 2 - 5 } Waktu & $\mathrm{n}$ & $\%$ & $\mathrm{n}$ & $\%$ & \\
Taat & 20 & 91,0 & 6 & 27,3 & 0,000 \\
Tidak taat & 2 & 9,0 & 16 & 72,7 & \\
\hline Jenis Obat & 22 & 100 & 21 & 22 & 0,312 \\
Taat & 0 & 0 & 1 & 0 & \\
Tidak taat & & & & & \\
\hline Dosis Obat & 22 & 100 & 21 & 22 & 0,312 \\
Taat & 0 & 0 & 1 & 0 & \\
Tidak taat & & & & & \\
\hline Sesuai & & & & & \\
Program & 22 & 100 & 21 & 95,4 & 0,312 \\
Taat & 0 & 0 & 1 & 4,6 & \\
Tidak taat & & & & & \\
\hline
\end{tabular}

Berdasarkan tabel 4.6 diatas ketaatan berdasarkan waktu nilai $\mathrm{p}<0,05$ menunjukkan secara statistik pendampingan PMO memberi pengaruh pada ketaatan minum obat sedangkan jenis obat, dosis obat, program nilai $p>0,05$ tidak ada pengaruh PMO tehadap ketaatan. 


\section{PEMBAHASAN}

1. Ketaatan berdasarkan waktu

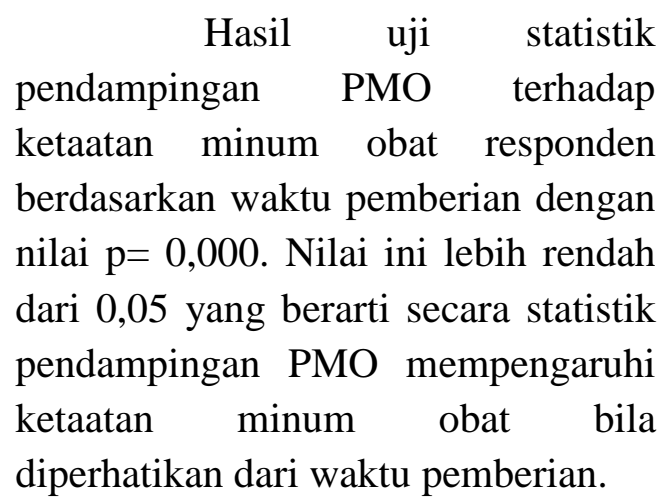

Ketaatan merupakan

bagian dalam diri indivudu untuk bersikap, berfikir dalam menyelesaikan suatu program terapi. Sehingga pada akhirnya klien sendirilah yang merasakan efek keberhasilan (Kemenkes, 2015).Pengawas Minum Obat adalah seorang yang bertugas untuk mengawasi klien agar menelan obat, berobat, memeriksakan diri, secara teratur sampai selesainya pengobatan, dan sekaligus memberikan penyuluhan pada keluarga yang memiliki resiko tuberkulosis, atau yang memiliki anggota keluarga yang menderita tuberkulosis sehingga dapat melakukan pencegahan sedini mungkin (Kemenkes, 2014). Dukungan keluarga merupakan bagian terpenting yang tak boleh dilulupakan, dimana salah satu program PMO adalah peran penting keluarga dalam memfasilitasi klien hingga menyelesaikan program pengobatan tuberculosis Kemenkes (2015). Hasil penelitian Nugroho (2011) bahwa (88\%) dukungan keluarga mempengaruhi klien dalam menyelesaikan pengobatan melalui dukungan emosional, dukungan penghargaan, dukungan instrumental, dan dukungan informatif.

Hasil penelitian ini sesuai dengan pendapat diatas dimana pada uji statistik pada kelompok intervensi responden menunjukkan hasil yang mendukung ketaatan minum obat klien tuberkulosis. Hasil penelitian ini juga sesuai dengan penelitian yang dilakukan oleh Irawati, 2014 dengan judul peran pengawas minum obat sebagai indikator keberhasilan pengobatan TB pada pasien koinfeksi tb - hiv di RSUD Dok II Jayapura periode januari 2011september 2012. Menekankan bahwa efek samping obat tuberculosis menjadi salah satu kendala selama pengobatan klien tuberculosis sehingga peran Pengawas Minum Obat (PMO) yang berasal dari keluarga inti mampu membantu klien menyelesaikan pengobatan. Dari jumlah 124 sampel yang diambil ternya 35 klien adalah klien default yang mengalami efek samping obat dan tidak memiliki Pengawas Minum Obat.

2. Ketaatan berdasarkan jenis obat, dosis obat, dan program

Hasil uji $r$ statistik
pendampingan PMO terhadap
ketaatan minum obat berdasarkan
jenis obat, dosis obat dan program
dengan nilai $\quad$ masing-masing


$\mathrm{p}=0,312$. Nilai ini lebih besar dari 0,05 yang berarti secara statistik pendampingan PMO tidak mempengaruhi ketaatan minum obat berdasarkan jenis obat, dosis obat dan program.

Ketaatan merupakan bagian dalam diri indivudu untuk bersikap, berfikir dalam menyelesaikan suatu program terapi. Sehingga pada akhirnya klien sendirilah yang merasakan efek keberhasilan (Kemenkes, 2015).

Program DOTS adalah meningkatkan dan memperluas pelayanan Directly Observed Treatment Short-course (DOTS) atau strategi penanggulangan tuberculosis yang berkualitas agar dapat menjangkau seluruh klien tuberkulosis, meningkatkan penemuan kasus dan keberhasilan pengobatan, menetapkan intervensi untuk menghadapi tantangan Tuberkulosis/HIV dan Multi Drug Resistance (MDR-TB), memperkuat kemitraan dalam menyediakan akses dan standar pelayanan yang diperlukan bagi seluruh klien tuberkulosis dan berkontribusi dalam penguatan sistem kesehatan (Kemenkes, 2015). Salah satu rencana strategi Program DOTS adalah Pengawas Minum Obat (PMO). Pengawas Minum Obat adalah seorang yang bertugas untuk mengawasi klien agar menelan obat, berobat, memeriksakan diri, secara teratur sampai selesainya pengobatan, dan sekaligus memberikan penyuluhan pada keluarga yang memiliki resiko tuberkulosis, atau yang memiliki anggota keluarga yang menderita tuberkulosis sehingga dapat melakukan pencegahan sedini mungkin (Kemenkes, 2014). Hasil penelitian ini tidak sesuai dengan pendapat diatas dimana sebagian besar responden pada kelompok intervensi dan kontrol pada hasil uji statistik didapatkan hasil pendampingan PMO tidak mempengaruhi ketaatan minum obat berdasarkan jenis obat, dosis obat dan program pengobatan. Hasil penelitian ini juga tidak sesuai dengan penelitian yang dilakukan olehNugroho (2011) bahwa (88\%) dukungan keluarga mempengaruhi klien dalam menyelesaikan pengobatan melalui dukungan emosional, dukungan penghargaan, dukungan instrumental, dan dukungan informatif. Hasil penelitian lain dari Hendiani dkk, (2012) tujuan untuk menilai persepsi dukungan keluarga terhadap kepatuhan minum obat, penelitian dilakukan di BKPM Semarang dengan studi kuantitatif purposif sampling pada 44 klien tuberkulosis ada hubungan yang signifikan antara dukungan keluarga terhadap kepatuhan minum obat dengan nilai $(\mathrm{p}<0,05)$ dengan kesimpulan bahwa bila dukungan keluarga tidak maksimal maka indikasi 
kepatuhan semakin tinggi sehingga dapat menyebabkan kegagalan pengobatan klien tuberkulosis. Ketidak sesuaian hasil penelitian ini dapat disebabkan oleh beberapa faktor yang mempengaruhi responden, salah satunya yaitu:

a. Panduan OAT di sediakan dalam bentuk paket Paduan Obat Anti Tuberkulosis (OAT) disediakan dalam bentuk paket, dengan tujuan untuk memudahkan pemberian obat dan menjamin kelangsungan (kontinuitas) pengobatan sampai selesai. Satu (1) paket untuk satu (1) pasien dalam satu (1) masa pengobatan.

1) Paket Kombipak.

Adalah paket obat lepas yang terdiri dari Isoniasid, Rifampisin, Pirazinamid dan Etambutol yang dikemas dalam bentuk blister. Paduan OAT ini disediakan program untuk digunakan dalam pengobatan pasien yang terbukti mengalami efek samping pada pengobatan dengan OAT KDT sebelumnya.

Obat Anti Tuberkulosis (OAT) disediakan dalam bentuk paket KDT mempunyai beberapa keuntungan dalam pengobatan TB, yaitu: a) Dosis obat dapat disesuaikan dengan berat badan sehingga menjamin efektifitas obat dan mengurangi efek samping.

b) Mencegah penggunaan obat tunggal sehinga menurunkan resiko terjadinya resistensi obat ganda dan mengurangi kesalahan penulisan resep

c) Jumlah tablet yang ditelan jauh lebih sedikit sehingga pemberian obat menjadi sederhana dan meningkatkan kepatuhan klien (Kemenkes, 2015).

\section{E. KESIMPULAN}

1. Karakteristik responden sebagian besar pada jenis kelamin perempuan, pendidikan SMA, lama menderita TB 0-3 bulan dan 4-6 bulan, klasifikasi TB baru.

2. Ketaatan responden sebagian besar taat pada jenis obat, dosis obat, sesuai program pada kelompok intervensi dan kontrol hanya ketaatan berdasarkan waktu responden sebagian besar pada kelompok kontrol tidak taat.

3. Hasil uji statistik didapatkan ada pengaruh pendampingan PMO terhadap ketaatan minum obat berdasarkan waktu, sedangkan pada ketaatan berdasarkan jenis obat, dosis obat, sesuai progam tidak adapengaruh.

4. Hipotesis bahwa pendampingan PMO dapat membantu ketaatan minum obat berdasar waktu di terima. Sedangkan 
ketaatan berdasarkan jenis obat, dosis obat, sesuai program di tolak.

\section{F. DAFTAR PUSTAKA}

Ariani, N. W., \& et al. (2015). FaktorFaktor Yang Berhubungan Dengan Keteraturan Minum Obat Penderita Tuberkulosis Paru Di Wilayah Kerja Puskesmas Modayag, Kabupaten Bolaang Mongondow Timur. Artikel Jurnal, Vol.5 No.1. 157-168.

Black, J. M. (2014). Medical-Surgical Nursing Clinical Management for Positive Outcomes. Singapore: ELSEVIER.

Black, J. M. (2010). Medical-Surgical Nursing Clinical Management for Positive Outcomes. Singapore: ELSEVIER.

Chida, N. (2015). Determinants of Default from Tuberculosis Treatment among Patients with Drug Susceptible Tuberculosis in Karachi, Pakistan: A Mixed Methods Study. Pakistan: PLOS. ONE.

Dharma, K.K. (2011). Metodologi Penelitian Keperawatan Panduan Melaksanakan dan Penerapkan Hasil Pnelitian. Jakarta: Trans Info Media

Depkes. (2009). Profil Kesehatan Indonesia. Jakarta: Departemen Kesehatan Republik Indonesia.

Dinkes, P. B. (2013). Data dan Informasi Kesehatan Provinsi Papua Barat.
Manokwari: Dinkes Provinsi Papua Barat.

Fauziyah, N. (2010). Faktor-faktor yang berhubungan dengan drop out pengobatan pada penderita TB Paru di Balai Pengobatan Penyakit ParuParu (BP4) Salatiga. Semarang.

Hendiani, N., \& et al. (2012). The Relationship Between Perceived Family Support As

DrugConsumption

Controller/Pengawas Minum Obat (PMO)'S And Self Efficacy of Tuberculosis Patient in BKPM Semarang Region. Jurnal Psikologi, Vol. 1. 94-105.

Hinkle, J. L., \& Cheever, K. H. (2014). BRunner \& Suddarth'S. Philadelphia. New York. London: Wolters Kluver.

Hungu. (2007). Demografi Kesehatan Indonesia. Jakarta: Grasindo.

Ignatuvicius, W., \& Suddarth'S, B. \&. (2010). Medical Surgical Nursing. St. Louis: ELSEVIER.

Kemenkes. (2014). Pedoman Nasional Pengendalian Tuberkulosis. Jakarta: Kemenkes.

Kemenkes. (2015). Pusat Data dan Informasi Temukan Obat Sampai Sembuh. Jakarta.

Kemenkes. (2015). Strategi Nasional Pengendalian TB di Indonesia.

Lewis. (2011). Medical Surgical Nursing. St. Louis: ELSEVIER. 
lupulalan, O. (2012). Analisis Faktor-Faktor yang Berhubungan dengan Kejadian Drop Out Penderita TB Paru di Puskesmas Kota Sorong Tahun 2011. Semarang: Universitas Diponegoro Program Pascasarjana Program Magister Ilmu Kesehatan Masyarakat Konsentrasi Administrasi dan Kebijakan Kesehatan.

Nugroho, R. A. (2011). Studi kualitatif faktor yang melatarbelakangi drop out pengobatan tuberkulosis paru. Jurnal kesehatan masyarakat, 83-09.

Peterson, S. J., \& Bredow, T. S. (2013). Middle Range Theories Application to Nursing Research. Philadelphia: Wolters Kluwer.

Phillips, P. P. (2013). An Evaluation of Culture Results during Treatment for Tuberculosis as Surrogate Endpoints for Treatment Failure and Relapse. Amerika: PLOS. ONE.

Polit, F. \&. (2010). Nursing Reseach: principles and Methods. 6th ed,. Philadelphia: Lapincott.

Rab, H. T. (2010). Ilmu Penyakit Paru. Jakarta: CV. Trans Info Media.

Rokhmah, D. (2013). Gender dan Penyakit Tuberkulosis: Implikasinya Terhadap Akses Layanan Kesehatan Masyarakat Miskin yang Rendah. Kesmas Artikel Penelitian, Vol.7 No.10.447-452.

Salim, S. A. (2010). Timing of Initiation of Antiretroviral Drugs during
Tuberculosis Therapy. N Engl J Med, 362:697-706.

Sineri, F. (2013). Pelaksanaan Program Penanggulangan Tuberkulosis Paru dengan Strategi DOTS di Wilayah Kerja Puskesmas Kabupaten Waropen Provinsi Papua. Semarang: Jurnal UNDIP.

Setiadi (2013). Konsep dan Praktik

Penulisan Riset Keperawatan. Edisi

2. Jakarta: Graha Ilmu.

Suddarth's, B. \&. (2014). Textbook of Medical Surgical Nursing. Philadelphia: Wolters Kluwer.

Suswati, E. (2006). Hubungan Tingkat Pendidikan dengan Kepatuhan Minum Obat Pada Penderita Tuberkkulosis. Jurnal Unej. Pengembangan Pendidikan, 67-73.

Tirtana, M. (2011). Faktor- Faktor yang Mempengaruhi Keberhasilan Pengobatan pada Pasien Tuberkulosis Paru dengan Resistensi Obat Anti Tuberkulosis di Wilayah Jawa Tenga. Semarang: Universitas Diponegoro .

Wahid Iqbal Mubarak, N. C. (2008). Buku Ajar Kebutuhan Dasar Manusia Teori \& Aplikasi dalam Praktek. Jakarta: EGC.

WHO. (2015). Global Tuberculosis Report.

Zulkifli Amin, A. B. (2014). Buku Ajar Ilmu Penyakit Dalam Edisi Keenam Jilid I. Jakarta: Pusat Penerbitan Ilmu Penyakit Dalam Diponegoro. 